\title{
Amyloid-like Fibril Formation by Trypsin in Aqueous Ethanol. Inhibition of Fibrillation by PEG
}

\author{
Márta Kotormán $^{\mathrm{a} *}$, L. Mária Simon ${ }^{\mathrm{a}}$, Attila Borics ${ }^{\mathrm{b}}$, Márton Richárd Szabóa,b, Kitti Szabó ${ }^{\mathrm{a}}$, Titanilla \\ Szögic and Lívia Fülöp ${ }^{c}$
}

\begin{abstract}
${ }^{a}$ Department of Biochemistry and Molecular Biology, Faculty of Science and Informatics, University of Szeged, Középfasor 52, H-6726 Szeged, Hungary; ${ }^{b}$ Laboratory of Chemical Biology, Biological Research Centre of Hungarian Academy of Sciences, Temesvári krt. 62, H-6726 Szeged, Hungary; ${ }^{c}$ Department of Medical Chemistry, University of Szeged, Dóm t. 8, H-6720 Szeged, Hungary
\end{abstract}

\begin{abstract}
The formation of amyloid-like fibrils was studied by using the well-known serine protease trypsin as a model protein in the presence of ethanol as organic solvent. Trypsin forms amyloid-like fibrils in aqueous ethanol at $\mathrm{pH}=7.0$. The dye Congo red $(\mathrm{CR})$ was used to detect the presence of amyloid-like fibrils in the samples. The binding of CR to fibrils led to an increase in absorption intensity and a red shift in the absorption band of CR. Thioflavin $\mathrm{T}$ (ThT) and 8-anilino-1naphthalenesulfonic acid (ANS) binding assays were employed to characterize amyloid-like fibril formation. The ThT binding assay revealed that the protein exhibited maximum aggregation in $60 \%(\mathrm{v} / \mathrm{v})$ ethanol after incubation for $24 \mathrm{~h}$ at $24{ }^{\circ} \mathrm{C}$. The ANS binding results indicated that the hydrophobic residues were more exposed to the solvent in the aggregated form of the protein. The effects of polyethylene glycol (PEG) on the formation of amyloid-like fibrils was studied in vitro. The aggregation of trypsin was followed via the kinetics of aggregation, the far-UV circular dichroism (CD) and transmission electron microscopy (TEM) in the presence and absence of PEG. The CD measurements indicated that the protein aggregates have a cross-beta structure in 60\% ethanol. TEM revealed that trypsin forms fibrils with a thread-like structure. The inhibitory effect of PEG on the aggregation of trypsin increased with rising PEG concentration. PEG therefore inhibits the formation of amyloid-like fibrils of trypsin in aqueous ethanol.
\end{abstract}

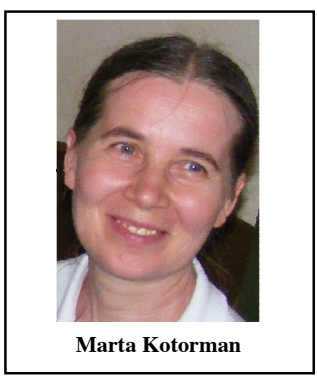

Keywords: Amyloid-like fibril, trypsin, organic solvent, polyethylene glycol, circular dichroism, Congo red.

\section{INTRODUCTION}

Approximately 50 human disorders are currently known to be associated with the misfolding of normally soluble peptides and proteins, and their subsequent conversion into insoluble, highly ordered amyloid fibrils [1]. Amyloid fibrils contribute to the complications in diseases such as the spongiform encephalopathies, Alzheimer's, Parkinson's and Huntington's diseases, type II diabetes mellitus, and primary and secondary systemic amyloidosis [2], which affect millions of people worldwide. It is important to study the behaviour not only of peptides and proteins that are associated with known diseases, but also of those that do not give rise to any pathogenic condition. This reflects a well-defined structural form of the protein that is an alternative to the native state - a form that may in principle be adopted by many, if not all, polypeptide sequences [1]. Most peptides and proteins have the potential to form amyloid fibrils under appropriate conditions; amyloid is a generic form of protein conformation, and the ability to form amyloid structures may be a general property of the polypeptide backbone [3-5]. The

*Address correspondence to this author at the Department of Biochemistry and Molecular Biology, Faculty of Science and Informatics, University of Szeged, H-6726 Szeged, Középfasor 52, Hungary; Tel: +36-62-544543; Fax:+36-62-544887; E-mail: kotorman@expbio.bio.u-szeged.hu in vitro aggregation of water-soluble proteins can often be observed under mild denaturing conditions, at high temperature, at $\mathrm{pH}$ values close to the isoelectric point or in the presence of polar organic solvents [6]. Such conditions promote aggregation because they result in the partial unfolding of structured proteins and they allow the sampling of locally unfolded native-like states, both of which are possibly amyloidogenic states [7]. It has been demonstrated experimentally that the surface charges play an important role in the aggregation of proteins $[8,9]$.

The stabilization of the native folded structure of a protein through the action of chemical compounds can markedly inhibit its unfolding and increase the energy barrier of fibrillation, and can therefore serve as an effective therapeutic strategy against protein deposition diseases [10-12]. Recently, some authors have reported on inhibition of fibrillation as well as destabilization of preformed fibrils using polyphenols $[13,14]$. Polyethylene glycols (PEGs) are nontoxic, biocompatible, water-soluble, hydrophilic non-ionic polymers that can interact with proteins through hydrogenbonding or hydrophobic interactions [15-17]. They have potential protective effects on various types of protein denaturation [18]. PEGs with high molecular weight stabilize proteins through a preferential hydration mechanism [19, 20]. Depending on the nature of the protein and the experimental 
conditions, PEGs can facilitate or inhibit protein aggregation $[21,22]$. PEG treatment after traumatic brain injury reduces the accumulation of $\beta$-amyloid precursor protein in degenerating axons [23]. Long-chain PEGs (PEG 20,000 and PEG $35,000)$ prevent the alkali-salt mediated fibrillation of hen egg white lysozyme at alkaline $\mathrm{pH}$ by stabilizing its native state, thereby preventing $\beta$-sheet formation [24].

Trypsin, a well-known serine protease, with a polypeptide chain of 223 amino acid residues and contains six disulfide bridges. Its catalytic triad is composed of serine, histidine and aspartic acid residues. Trypsin is a globular protein with a predominance of antiparallel $\beta$-sheet and $\alpha$-helix in its secondary structure. Trypsin is composed of two domains, in both of which 6 strands form an anti-parallel betabarrel in the native structure of trypsin [25-27]. Trypsin forms different secondary structures in organic solvents, depending on the nature and concentration of the solvent, circular dichroism (CD) measurements indicating that the extent of $\beta$-sheet structure formation varies in the range $31-$ $61 \%$ at $\mathrm{pH} 3.0[28,29]$.

We report here the in vitro formation of amyloid-like fibrils by trypsin in aqueous ethanol at $\mathrm{pH}=7.0$ in the presence or absence of different polyols. However, unfortunately at $\mathrm{pH}=7.0$ autolysis proceeds. The autolysis can alter the formation of amyloid fibrils, thus it is necessary to modify the serine residue at the active site of the enzyme with PMSF. The PMS-trypsin is inactive. PMSF binds specifically to a serine residue in the active site of serine protease [30]. The amyloid-like formation by trypsin was studied by measuring the kinetics of aggregation, through thioflavin $\mathrm{T}$ (ThT), 8-anilino-1-naphthalenesulfonic acid (ANS) and Congo red (CR) binding assays and $\mathrm{CD}$ measurements, and by means of transmission electron microscopy (TEM).

\section{MATERIALS AND METHODS}

\subsection{Materials}

Trypsin (EC 3.4.21.4; from the bovine pancreas), ANS, ThT (4-(3,6-dimethylbenzothiazol-2-yl)-N,N-dimethylaniline), and $N$-benzoyl-L-arginine ethyl ester (BAEE) were purchased from Sigma-Aldrich. PEG (average molecular weight 2000) was from Fluka. All other reagents and buffer components used were of analytical grade.

\subsection{Enzymatic activity assay}

The measurement of trypsin activity was based on spectral differences between BAEE and the carboxylate form of $\mathrm{N}$-benzoyl-L-arginine. Enzymatic activity was determined according to Schwert and Takenaka [31] by measuring the increase in absorbance at $253 \mathrm{~nm}$ in a reaction mixture at $\mathrm{pH}$ 8.0. Reactions were initiated by the addition of $20 \mu 10.15$ $\mathrm{mg} / \mathrm{ml}$ enzyme solution from the different samples.

\subsection{Modification of trypsin with phenylmethylsulfonyl fluoride (PMSF)}

The reaction of trypsin with PMSF modifies the serine residue at the active site of the enzyme, inactivating it. This is necessary because the autolysis of trypsin at neutral $\mathrm{pH}$ can alter its formation of amyloid fibrils. Solutions of $8.4 \mu \mathrm{l}$ PMSF $(100 \mathrm{mM})$ in 2-propanol and $20 \mu \mathrm{l}$ trypsin $(50 \mathrm{mg} / \mathrm{ml}$ in $0.001 \mathrm{~N} \mathrm{HCl}$ ) were added at $24{ }^{\circ} \mathrm{C}$ to $2 \mathrm{ml} 0.05 \mathrm{M}$ potassium phosphate buffer $(\mathrm{pH}=7.0)$ with stirring. Such aliquots were added to the buffer on four occasions. The reaction was allowed to proceed for $30 \mathrm{~min}$. To remove the excess reagent, the solution was then filtered on Sephadex G-25, followed by elution with $0.05 \mathrm{M}$ potassium phosphate buffer $(\mathrm{pH}=7.0)$. The enzymatic activity assays revealed that $95 \%$ of the trypsin was modified.

\subsection{ANS binding}

ANS binding assays were performed on a Hitachi F-2500 FL fluorescence spectrophotometer, using $50 \mu \mathrm{M}$ ANS solution with $30 \mu \mathrm{g} / \mathrm{ml}$ protein, in the absence or presence of $60 \%$ ethanol. The fluorescence spectra were recorded $30 \mathrm{~min}$ after the addition of ANS to the protein aliquots. The excitation wavelength was $365 \mathrm{~nm}$ and the emission was collected between $400 \mathrm{~nm}$ and $600 \mathrm{~nm}$. The emission and excitation monochromator slit widths were 10 and $5 \mathrm{~nm}$,_respectively.

\subsection{ThT binding assay}

Trypsin fibril formation was monitored in ThT binding assays. Samples containing $300 \mu \mathrm{g} / \mathrm{ml}$ trypsin were incubated at $24{ }^{\circ} \mathrm{C}$ for $24 \mathrm{~h}$ in various concentration of ethanol. $100 \mu \mathrm{l}$ of protein sample was then diluted into buffer $(10$ $\mathrm{mM}$ phosphate, $150 \mathrm{mM} \mathrm{NaCl}, \mathrm{pH} 7.0$ ) containing $65 \mu \mathrm{M}$ ThT. 5 min after the addition of the protein aliquot, the fluorescence intensity was recorded. The emission was measured at $485 \mathrm{~nm}$ and the excitation wavelength was $440 \mathrm{~nm}$. The emission and excitation monochromator slit widths were 10 and $5 \mathrm{~nm}$, respectively.

\subsection{CR binding}

Amyloid-specific CR binding assays were carried out in $5 \mathrm{mM}$ phosphate buffer ( $\mathrm{pH} 7.0$ ) containing $150 \mathrm{mM} \mathrm{NaCl}$. The final concentrations of $\mathrm{CR}$ and protein were $11 \mu \mathrm{M}$ and $26 \mu \mathrm{g} / \mathrm{ml}$, respectivelly. Aliquots $(200 \mu \mathrm{l})$ taken from 1-dayaged trypsin samples containing $60 \%$ ethanol at $\mathrm{pH}=7.0$ were combined with $0.8 \mathrm{ml} \mathrm{CR}$ solution, and incubated for $15 \mathrm{~min}$ at room temperature before the measurements. The absorption spectra of CR were recorded in the wavelength region $400-600 \mathrm{~nm}$ in a $10 \mathrm{~mm}$ pathlength cell. The presence of trypsin amyloid-like fibrils was indicated by characteristic spectral changes: a red shift of the absorption band and an increase in absorption intensity. The spectra of CR alone and the protein alone were subtracted from spectrum of trypsin + $\mathrm{CR}$, yielding the difference spectrum. The shape of the difference spectra clearly revealed the spectral change in the presence of amyloid fibrils.

\subsection{Turbidity measurements}

Turbidity at $350 \mathrm{~nm}$ was followed at $24{ }^{\circ} \mathrm{C}$ in a $10 \mathrm{~mm}$ pathlength cell in the presence or absence of different polyols in $60 \%$ ethanol. The PMS-trypsin concentration in the turbidity experiments was $0.15 \mathrm{mg} / \mathrm{ml}$ in $10 \mathrm{mM}$ phosphate buffer, $\mathrm{pH}$ 7.0. The samples were incubated for $24 \mathrm{~h}$ before measurements. 


\subsection{Aggregation kinetics}

Aggregation kinetic assays were performed in buffered $60 \%$ ethanol on a Hitachi U-2000 spectrophotometer by monitoring the absorption at $350 \mathrm{~nm}$ during $30 \mathrm{~min}$ at $24{ }^{\circ} \mathrm{C}$ in the presence or absence of PEG 2000 at pH 7.0. The enzyme concentration was $0.13 \mathrm{mg} / \mathrm{ml}$ in $60 \%$ ethanol.

\subsection{CD measurements}

$\mathrm{CD}$ measurements were used to determine the changes in protein secondary structure in the peresence of $60 \%$ ethanol. CD spectra were recorded in the far UV range from 185 to $260 \mathrm{~nm}$, in a $0.01 \mathrm{~cm}$ pathlength quartz cell on a Jasco J-815 $\mathrm{CD}$ spectrometer at $24^{\circ} \mathrm{C}$. The PMS-trypsin was dissolved in potassium phosphate buffer (final concentration $10 \mathrm{mM}, \mathrm{pH}$ 7.0). The CD spectra were recorded in the presence of 50 $\mathrm{mg} / \mathrm{ml}$ PEG 2000 in buffered $60 \%$ ethanol, in buffered $60 \%$ ethanol and in buffer. The enzyme concentration was 0.15 $\mathrm{mg} / \mathrm{ml}$. The ellipticity, $(\Theta)$, was expressed in $\mathrm{mdeg}$.

\subsection{Transmission electron microscopy (TEM)}

$10 \mu \mathrm{l}$ aliquots of the protein solutions were placed on carbon-coated 400-mesh copper grids (Electron Microscopy Sciences, Washington, PA, USA) and stained with $2 \%(\mathrm{w} / \mathrm{v})$ uranyl acetate. Images were taken on a Philips CM 10 transmission electron microscope (FEI Company, Hillsboro, OR, USA) operating at $100 \mathrm{kV}$. Images were captured with a Megaview II Soft Imaging System, routinely at magnifications of $\times 46,000$ and $\times 64,000$, and analysed with an AnalySis ${ }^{\circledR} 3.2$ software package (Soft Imaging System GmbH, Münster, Germany).

\section{RESULTS AND DISCUSSION}

A variety of experimental methods, including ThT, ANS, $\mathrm{CR}$ binding assays, aggregation kinetics, turbidity and $\mathrm{CD}$ measurements and TEM were employed to follow the aggregation of the enzyme. Amyloid-like fibril formation was observed in aqueous ethanol at $\mathrm{pH}$ 7.0. The aggregation of trypsin was studied in ethanol at different concentrations. The ThT fluorescence intensity at $485 \mathrm{~nm}$ increases markedly upon binding to the surface of the crossed $\beta$-sheet structured amyloid fibrils [32]. The investigations of ThT binding demonstrated that maximum fibril formation was observed in $60 \%$ ethanol after incubation for $24 \mathrm{~h}$ at $24^{\circ} \mathrm{C}$ (Fig. 1).

Hydrophobic interactions of ANS with proteins is one of the methods commonly used in studies of protein folding and amyloid fibril formation for the detection and characterization of partially folded and molten globule states of proteins. ANS is a non-covalent extrinsic fluorescent probe; its quantum yield is increased up to 100 times upon binding to hydrophobic regions of a protein, together with a blue shift of the emission maximum $[33,34]$. We succeeded in determining the loosening of the protein structure by ANS binding to the hydrophobic region of the partially unfolding protein in $60 \%$ ethanol. The ANS fluorescence proved to be increased and its binding was accompanied by a blue shift of $22 \mathrm{~nm}$ (from $512 \mathrm{~nm}$ to $490 \mathrm{~nm}$ ) upon binding with the protein (Fig. 2). This clearly indicates the conformational changes of trypsin in the presence of ethanol.

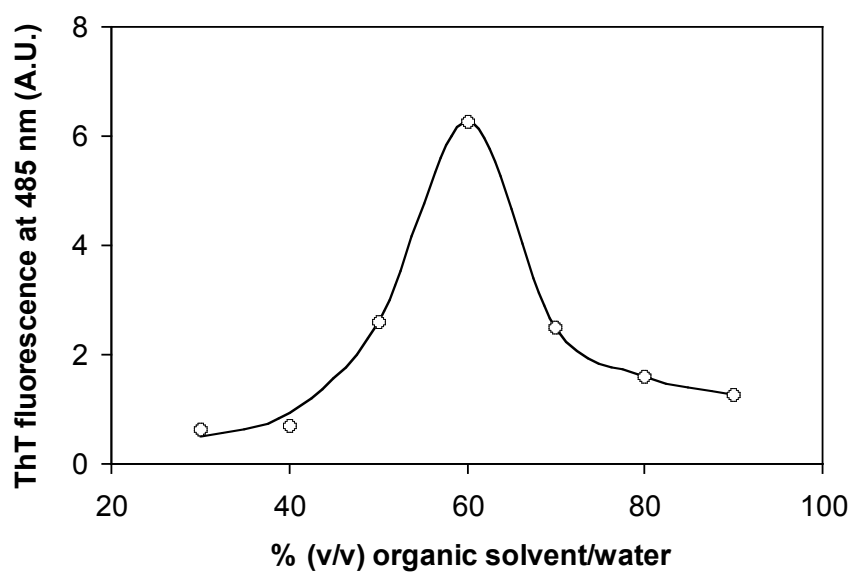

Figure 1. Dependence of ThT binding on the ethanol concentration after incubation for $24 \mathrm{~h}$ at $24{ }^{\circ} \mathrm{C}(\mathrm{O})$; enzyme concentration: 30 $\mu \mathrm{g} / \mathrm{ml}$.

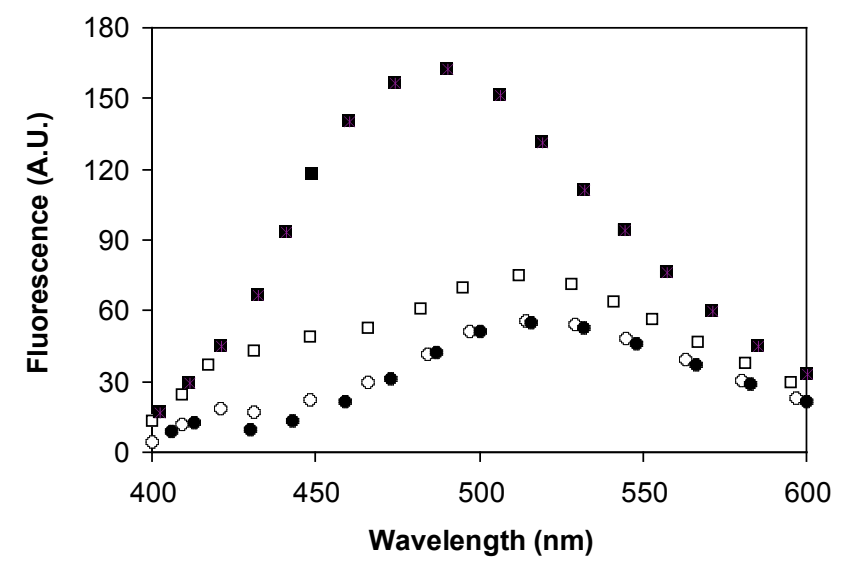

Figure 2. Fluorescence spectra of trypsin-ANS in $5 \mathrm{mM}$ sodium phosphate buffer $(\mathrm{pH}=7.0)(\bullet)$, in $60 \%$ ethanol ( $\bullet$ ) after incubation at $24{ }^{\circ} \mathrm{C}$ for $24 \mathrm{~h}$, and of ANS alone in buffer (O) and in $60 \%$ ethanol ( $\square$ ); enzyme concentration: $30 \mu \mathrm{g} / \mathrm{ml}$.

The turbidity measurements were performed to detect the effects of different polyols on the aggregation of the protein. These experiments revealed that the greatest effect was exerted by PEG 2000 in $60 \%$ ethanol. In the presence of 50 $\mathrm{mg} / \mathrm{ml}$ PEG 2000, the absorption at $350 \mathrm{mn}$ had decreased to $41.9 \%$ after incubation for $24 \mathrm{~h}$ relative to the sample not containing PEG 2000 (Fig. 3). Our results have shown, that the number of the hydroxyl groups of the sugars not only are responsible for their inhibitory potency, but also the configuration of hydroxyl groups are important. The D-ribose and the L-arabinose contains the same number of hydroxyl groups, however their inhibitory effect are different.

The aggregation kinetic assays were performed to establish the effects of PEG 2000 on the protein aggregation. The kinetics of aggregation of PMS-trypsin in $60 \%$ ethanol was investigated by monitoring the time-dependent changes in the absorption at $350 \mathrm{~nm}$ in the presence or the absence of PEG 2000 at $\mathrm{pH}=7.0$. The absorption at $350 \mathrm{~nm}$ was monitored for $30 \mathrm{~min}$, with readings every minute. It has been demonstrated that the secondary structure-retaining effect of 


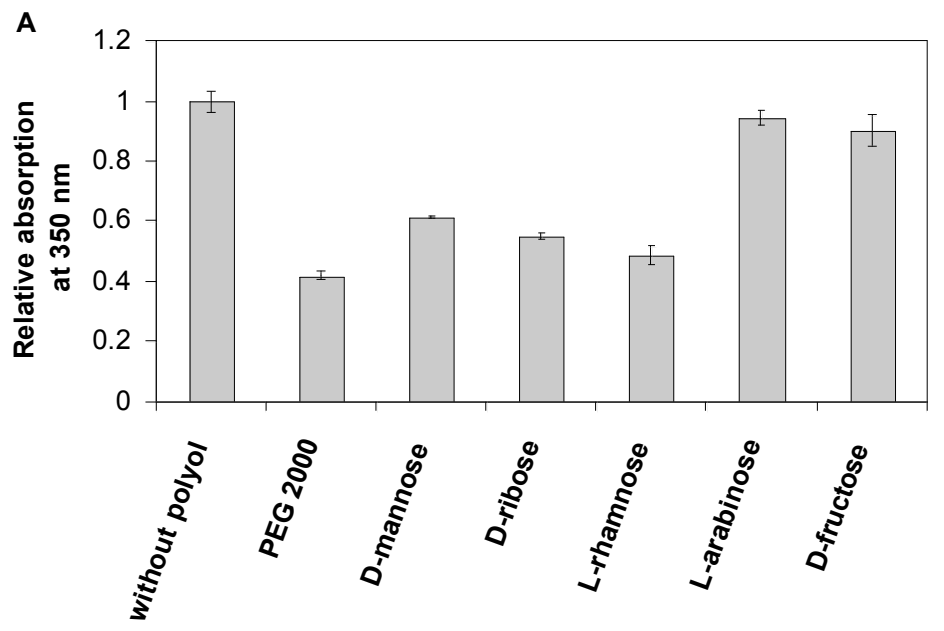

B

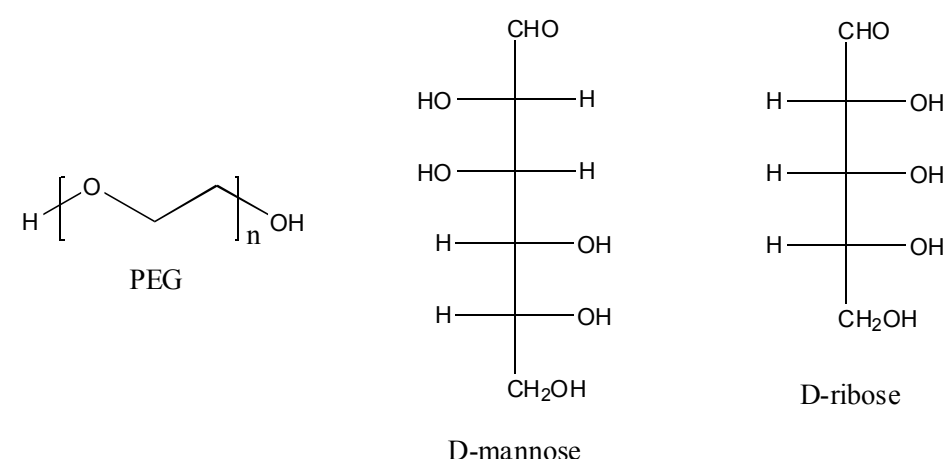

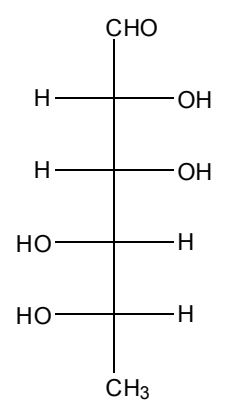

L-rhamnose

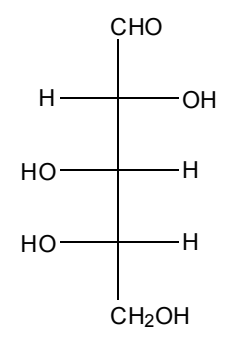

L-arabinose

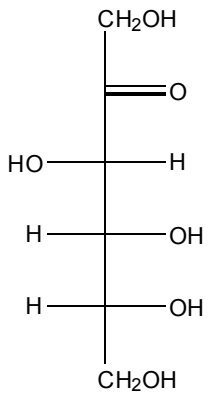

D-fructose

Figure 3 (A). Turbidity changes of PMS-trypsin at $24{ }^{\circ} \mathrm{C}$ at $\mathrm{pH} 7.0$ in $60 \%$ ethanol, monitored via the absorption at $350 \mathrm{~nm}$ after incubation for $24 \mathrm{~h}$ in the presence of various polyols or without polyol. Polyol concentration: $50 \mathrm{mg} / \mathrm{ml}$, PMS-trypsin concentration: $0.15 \mathrm{mg} / \mathrm{ml}$. (B) The chemical structures of the studied polyols.

polyols increases with increasing concentration and number of hydroxy groups [35]. PEG 2000 moderated the formation of amyloid-like fibrils to an extent depending on its concentration in 60\% ethanol (Fig. 4), indicating that PEG 2000 has a stabilizing effect on the protein structure. The inhibitory effect of PEG 2000 on the aggregation increased with rising concentration. These findings led to the conclusion that the stability of the native structure of trypsin can be increased by the presence of PEG, and aggregation can therefore be inhibited through the application of PEG.

The results of $\mathrm{CD}$ measurements support the changes in the secondary structure of protein in $60 \%$ ethanol. The $\mathrm{CD}$ spectra of PMS-trypsin were measured in the presence of PEG 2000 in buffered $60 \%$ ethanol and without PEG 2000 as compared with the CD spectrum of the protein in $10 \mathrm{mM}$ phosphate buffer at $\mathrm{pH} 7.0$ (Fig. 5). The CD spectrum of PMS-trypsin in $10 \mathrm{mM}$ phosphate buffer exhibited a positive maximum at $186 \mathrm{~nm}$ with an intense broad minimum between 211 and $217 \mathrm{~nm}$, thus the protein consists of a mixture of alpha-helices and beta-sheets. This spectrum indicates the dominance of the structure of the $\beta$-sheet, with the presence of the $\alpha$-helix. The maximum at $186 \mathrm{~nm}$ is primarily indicative of the presence of the $\alpha$-helix. The maximum of the protein with $\beta$-sheet structure is observed at around 195-200 


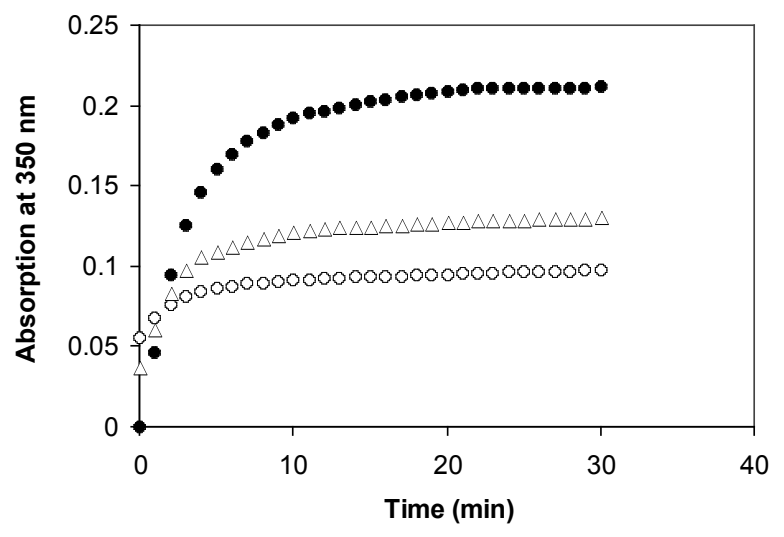

Figure 4. Kinetics of aggregation of PMS-trypsin in $60 \%$ ethanol without PEG $2000(\bullet)$, or in the presence of $50 \mathrm{mg} / \mathrm{ml}$ PEG 2000 (०) of $25 \mathrm{mg} / \mathrm{ml}$ PEG $2000(\Delta)$, monitored via the time-dependent increase in absorption at $350 \mathrm{~nm}$ at $\mathrm{pH}$ 7.0. Enzyme concentration: $0.13 \mathrm{mg} / \mathrm{ml}$.

$\mathrm{nm}$. In the case of the sample containing $60 \%$ ethanol, the maximum absorption characteristic of the $\alpha$-helix cannot be seen. The positive band at $195 \mathrm{~nm}$ and the negative band at $220 \mathrm{~nm}$ point to the $\beta$-sheet structure of the polypeptide chains, which is characteristic of amyloid fibrils. In the presence of $60 \%$ ethanol and $50 \mathrm{mg} / \mathrm{ml}$ PEG 2000, the maximum at $200 \mathrm{~nm}$ an intense negative band at $217-220 \mathrm{~nm}$ indicate the $\beta$-sheet structure. However, the discrete rise at $186 \mathrm{~nm}$, the shoulder at $210 \mathrm{~nm}$ on the broad minimum, and the stronger intensity as compared with that of the sample in $60 \%$ ethanol may refer to the partial presence of the $\alpha$-helix. The partial presence of the $\alpha$-helix shows that PEG stabilizes the native structure of the protein.

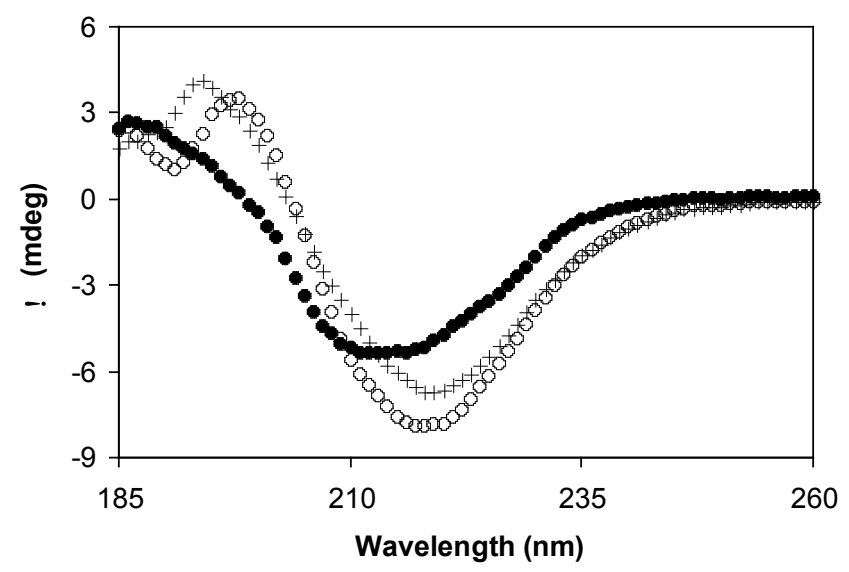

Figure 5. CD spectra of PMS-trypsin in $10 \mathrm{mM}$ phosphate buffer $(\mathrm{pH} 7.0)(\bullet)$, in $10 \mathrm{mM}$ phosphate-buffered $60 \%$ ethanol without PEG $2000(+)$ and in the presence of $50 \mathrm{mg} / \mathrm{ml}$ PEG 2000 (०); enzyme concentration: $0.15 \mathrm{mg} / \mathrm{ml}$.

One of the methods most commonly used for the detection of amyloid fibril formation is the CR binding assay. CR exhibits maximum absorption at $490 \mathrm{~nm}$. Its binding to $\beta$ sheet-rich amyloid fibrils induces a characteristic increase in absorption intensity and a red shift in the absorption band of CR from 490 to $540 \mathrm{~nm}$ [36]. Binding of the dye was detected both by an increase in the absorption intensity and by a red shift in the absorption maximum. The changes were better quantified by the difference spectrum between the dye-free situation and that when $\mathrm{CR}$ was incubated with the amyloid fibrils. The maximum spectral difference in ethanol in the absence of PEG 2000 was observed at $550 \mathrm{~nm}$ (Fig. 6). $\mathrm{CR}$ binding experiments suggested that the aggregates have amyloid-like properties. PEG 2000 is capable of inhibiting trypsin amyloid-like fibril formation in vitro in ethanol.
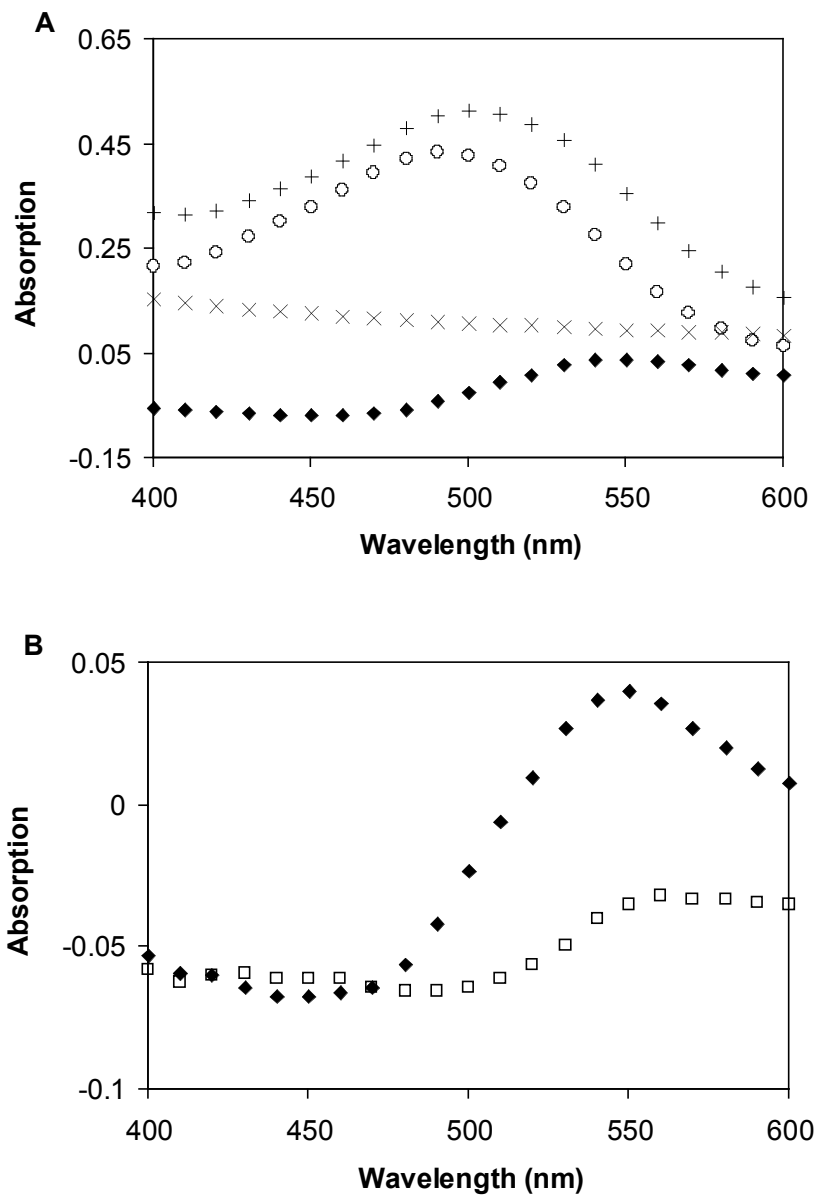

Figure 6. CR absorption and difference spectra of PMS-trypsin (A). PMS-trypsin + CR (+), CR alone (०), PMS-trypsin alone (x), difference spectrum in $60 \%$ ethanol $(\diamond)$. Difference spectra of PMStrypsin in $60 \%$ ethanol (B) in the presence of $50 \mathrm{mg} / \mathrm{ml}$ PEG 2000 $(\square)$ and without PEG $2000(\diamond)$. Final protein concentration: 26 $\mu \mathrm{g} / \mathrm{ml}$.

TEM images recorded after incubation for $24 \mathrm{~h}$ at $24{ }^{\circ} \mathrm{C}$ in the presence or the absence of PEG 2000 revealed that the trypsin aggregates have a fibrillar morphology in $60 \%$ ethanol (Fig. 7). The inhibitory effect of PEG 2000 on trypsin fibrillation was confirmed by TEM. In the presence of PEG we can observe the formation of non-fibrillar aggregates instead of the formation of amyloid fibrils. 
A

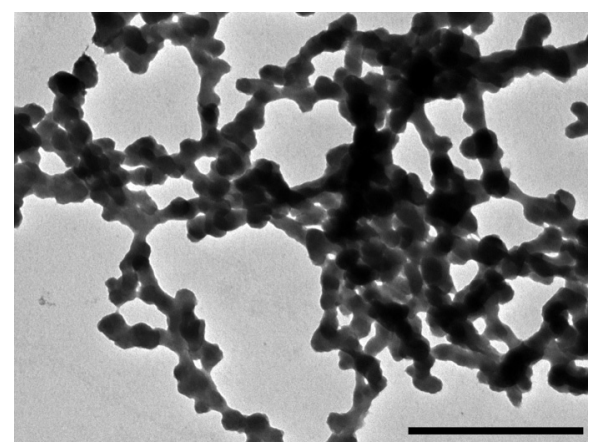

B

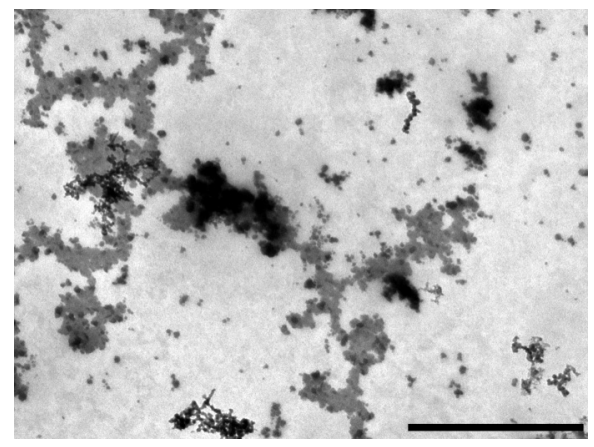

Figure 7. TEM micrographs of trypsin samples after incubation at $24{ }^{\circ} \mathrm{C}$ for $24 \mathrm{~h}$. PMS-trypsin in $60 \%$ ethanol (A), PMS-trypsin in $60 \%$ ethanol in the presence of $50 \mathrm{mg} / \mathrm{ml}$ PEG 2000 (B). The scale bar indicates $1 \mu \mathrm{m}$. Enzyme concentration: $0.13 \mathrm{mg} / \mathrm{ml}$ in ethanol.

In summary, we have demonstrated that trypsin forms amyloid-like fibrils at $\mathrm{pH} 7.0$ at $24{ }^{\circ} \mathrm{C}$ in aqueous ethanol. The greatest extent of formation of amyloid-like fibrils occurred in 60\% ethanol. PEG 2000 retarded trypsin aggregation because it stabilizes the native structure of trypsin against deleterious conformational changes, preventing protein-protein aggregation interactions. PEG 2000 inhibits the amyloid-like fibril formation of trypsin in ethanol.

\section{LIST OF ABBREVIATIONS}

$\begin{array}{ll}\mathrm{ANS} & =8 \text {-anilino-1-naphthalenesulfonic acid } \\ \mathrm{BAEE} & =\text { N-benzoyl-L-arginine ethyl ester } \\ \mathrm{CD} & =\text { circular dichroism } \\ \mathrm{CR} & =\text { Congo red } \\ \mathrm{PEG} & =\text { polyethylene glycol } \\ \mathrm{PMSF} & =\text { phenylmethylsulfonyl fluoride } \\ \mathrm{TEM} & =\text { transmission electron microscopy } \\ \mathrm{ThT} & =\text { thioflavin } \mathrm{T}\end{array}$

\section{CONFLICT OF INTEREST}

The authors confirm that this article content has no conflicts of interest.

\section{ACKNOWLEDGEMENTS}

This work was supported by project TÁMOP-4.2.2.A11/1/KONV-2012-0052.

\section{REFERENCES}

[1] Knowles, T.P.; Vendruscolo, M.; Dobson, C.M. The amyloid state and its association with protein misfolding diseases. Nat. Rev. Mol. Cell. Biol., 2014, 15(6), 384-396.

[2] Stefani, M. Protein misfolding and aggregation: new examples in medicine and biology of the dark side of the protein world. Biochim. Biophys. Acta, 2004, 1739(1), 5-25.

[3] Chiti, F.; Webster, P.; Taddei, N.; Clark, A.; Stefani, M.; Ramponi, G.; Dobson, C.M. Designing conditions for in vitro formation of amyloid protofilaments and fibrils. Proc. Natl. Acad. Sci. U S A, 1999, 96(7), 3590-3594.

[4] Dobson, C.M. Protein misfolding, evolution and disease. Trends Biochem. Sci., 1999, 24(9), 329-332.

[5] Ventura, S.; Lacroix, E.; Serrano, L. Insights into the origin of the tendency of the PI3-SH3 domain to form amyloid fibrils. J. Mol. Biol., 2002, 322(5), 1147-1158.

[6] Ohnishi, S.; Takano, K. Amyloid fibrils from the viewpoint of protein folding. Cell. Mol. Life Sci., 2004, 61(5), 511-524.

[7] Shokri, M.M.; Ahmadian, S.; Bemporad, F.; Khajeh, K.; Chiti, F. Amyloid fibril formation by a normally folded protein in the absence of denaturants and agitation. Amyloid, 2013, 20(4), 226-232.

[8] Rezaei-Ghaleh, N.; Ebrahim-Habibi, A.; Moosavi-Movahedi, A.A. Nemat-Gorgani, M. Role of electrostatic interactions in 2,2,2,trifluoroethanol-induced structural changes and aggregation of alpha-chymotrypsin. Arch. Biochem. Biophys., 2007, 457(2), 160169.

[9] Simon, L.M.; Laczkó, I.; Demcsák, A.; Tóth, D.; Kotormán, M.; Fülöp, L. The formation of amyloid-like fibrils of $\alpha$-chymotrypsin in different aqueous organic solvents. Protein Pept. Lett., 2012, 19(5), 544-550.

[10] Marinelli, P.; Castillo, V.; Ventura, S. Trifluoroethanol modulates amyloid formation by theall $\alpha$-helical URN1 FF domain. Int. J. Mol. Sci., 2013, 14(9), 17830-17844.

[11] Soldi, G.; Plakoutsi, G.; Taddei, N.; Chiti, F. Stabilization of a native protein mediated by ligand binding inhibits amyloid formation independently of the aggregation pathway. J. Med. Chem., 2006, 49(20), 6057-6064.

[12] Härd, T.; Lendel, C. Inhibition of amyloid formation. J. Mol. Biol., 2012, 421(4-5), 441-465.

[13] Shariatizi, S.; Meratan, A.A.; Ghasemi, A.; Nemat-Gorgani, M. Inhibition of amyloid fibrillation and cytotoxicity of lysozyme fibrillation products by polyphenols. Int. J. Biol. Macromol., 2015, 80, 95-106.

[14] Berhanu, W.M.; Masunov, A.E. Atomistic mechanism of polyphenol amyloid aggregation inhibitors: molecular dynamics study of Curcumin, Exifone, and Myricetin interaction with the segment of tau peptide oligomer. J. Biomol. Struct. Dyn., 2015, 33(7), 13991411.

[15] Ragi, C.; Sedaghat-Herati, M.R.; Ouameur, A.A.; Tajmir-Riahi, H.A. The effects of poly(ethylene glycol) on the solution structure of human serum albumin. Biopolymers, 2005, 78(5), 231-236.

[16] Hamada, H.; Arakawa, T.; Shiraki, K. Effect of additives on protein aggregation. Curr. Pharm. Biotechnol., 2009, 10(4), 400-407.

[17] Wu, J.; Wang, Z.; Lin, W.; Chen, S. Investigation of the interaction between poly(ethylene glycol) and protein molecules using low field nuclear magnetic resonance. Acta Biomater., 2013, 9(5), 6414-6420.

[18] Naseem, F.; Khan, R.H. Effect of ethylene glycol and polyethylene glycol on the acid-unfolded state of trypsinogen. J. Protein Chem., 2003, 22(7-8), 677-682.

[19] Bhat, R.; Timasheff, S.N. Steric exclusion is the principal source of the preferential hydration of proteins in the presence of polyethylene glycols. Protein Sci., 1992, 1(9), 1133-1143.

[20] Shimizu, S.; Smith, D.J. Preferential hydration and the exclusion of cosolvents from protein surfaces. J. Chem. Phys., 2004, 121(2), $1148-1154$.

[21] Ma, Q.; Fan, J.B.; Zhou, Z.; Zhou, B.R.; Meng, S.R.; Hu, J.Y.; Chen, J.; Liang, Y. The contrasting effect of macromolecular 
crowding on amyloid fibril formation. PLoS One, 2012, 7(4), e36288.

[22] Ma, B.; Xie, J.; Wei, L.; Li, W. Macromolecular crowding modulates the kinetics and morphology of amyloid self-assembly by $\beta$ lactoglobulin. Int. J. Biol. Macromol., 2013, 53, 82-87.

[23] Koob, A.O.; Borgens, R.B. Polyethylene glycol treatment after traumatic brain injury reduces beta-amyloid precursor protein accumulation in degenerating axons. J. Neurosci. Res., 2006, 83(8), 1558-1563.

[24] Ghosh, S.; Pandey, N.K.; Dasgupta, S. Crowded milieu prevents fibrillation of hen egg white lysozyme with retention of enzymatic activity. J. Photochem. Photobiol. B, 2014, 138, 8-16.

[25] Polgár, L. The catalytic triad of serine peptidases. CMLS Cell. Mol. Life Sci., 2005, 62, 2161-2172.

[26] Nagano, N.; Hutchinson, E.G.; Thornton, J.M. Barrel structures in proteins: automatic identification and classification including a sequence analysis of TIM barrels. Protein Sci., 1999, 8(10), 20722084.

[27] Bittar, E.R.; Caldeira, F.R.; Santos, A.M.C.; Günther, A.R.; Rogana E.; Santoro M.M. Characterization of $\beta$-trypsin at acid $\mathrm{pH}$ by differential scanning calorimetry. Braz. J. Med. Biol. Res., 2003, 36(12), 1621-1627.

[28] Simon, L.M.; Kotormán, M.; Garab, G.; Laczkó, I. Structure and activity of $\alpha$-chymotrypsin and trypsin in aqueous organic media. Biochem. Biophys. Res. Commun., 2001, 280(5), 1367-1371.

[29] Kotormán, M.; Laczkó, I.; Szabó, A.; Simon, L.M. Effects of $\mathrm{Ca}^{2+}$ on catalytic activity and conformation of trypsin and $\alpha$ - chymotrypsin in aqueous ethanol. Biochem. Biophys. Res. Commun., 2003, 304(1), 18-21.

[30] Sanatan P.T.; Lomate P.R.; Giri A.P.; Hivrale V.K. Characterization of a chemostable serine alkaline protease from Periplaneta americana. BMC Biochem., 2013, 14, 32.

[31] Schwert, G.W.; Takenaka, Y. A spectrophotometric determination of trypsin and chymotrypsin. Biochim. Biophys. Acta, 1955, 16, 570-575.

[32] Biancalana, M.; Makabe, K.; Koide, A.; Koide, S. Molecular mechanism of thioflavin-T binding to the surface of beta-rich peptide self-assemblies. J. Mol. Biol., 2009, 385, 1052-1063.

[33] Ali, V.; Prakash, K.; Kulkarni, S.; Ahmad, A.; Madhusudan, K.P.; Bhakuni, V. 8-anilino-1-naphthalene sulfonic acid (ANS) induces folding of acid unfolded cytochrome $\mathrm{c}$ to molten globule state as a result of electrostatic interactions. Biochemistry, 1999, 38(41), 13635-13642.

[34] Munishkina, L.A.; Fink, A.L. Fluorescence as a method to reveal structures and membrane-interactions of amyloidogenic proteins. Biochim. Biophys. Acta, 2007, 1768(8), 1862-1885.

[35] Naeem, A.; Ashraf, M.T.; Akram, M.; Khan, R.H. Comparative study of effects of polyols, salts, and alcohols on trichloroacetic acid-induced state of cytochrome C. Biochemistry (Mosc), 2006, 71(10), 1101-1109.

[36] Klunk, W.E.; Pettegrew, J.W.; Abraham, D.J. Two simple methods for quantifying low-affinity dye-substrate binding. J. Histochem. Cytochem., 1989, 37(8), 1293-1297. 